\title{
Analysis of water movement in paddy rice fields (II) simulation studies
}

\author{
Shih-Kai Chen ${ }^{\mathrm{a}}$, Chen Wuing Liu ${ }^{\mathrm{b}, *}$, Han-Chen Huang ${ }^{\mathrm{b}}$ \\ ${ }^{a}$ Chi-Sheng Water Management Research and Development Foundation, Taipei 10617, Taiwan, ROC \\ ${ }^{\mathrm{b}}$ Department of Agricultural Engineering, National Taiwan University, Taipei 10617, Taiwan, ROC
}

Accepted 10 July 2002

\begin{abstract}
Part (I) of this study presented field and laboratory experimental data on soil characteristics and hydraulic parameters that are related to water infiltration in rice paddy fields. Part (II) includes a series of numerical simulations that are based on the in situ data, which three-dimensional finite element computer model for simulating density dependent flow and transport (FEMWATER) produced to identify and evaluate the controlling factors in the vertical percolation/lateral seepage processes. As well, ground water recharge that resulted from the fields' infiltration is estimated. FEMWATER was first compared with one-dimensional simulation algorithm for water flow in aquatic habitats, as well as experimental data that were in good agreement. Simulation results indicated that the plow sole was the major factor that controls infiltration rate. Notably, infiltration is primarily a vertical downward flow within flooded areas. Significant lateral movement occurred only at wet to dry boundaries. The length of the wet to dry boundary, the area of the flooded paddy rice fields, and the difference in initial water content between flooded and dry field soils determined the ratio of lateral seepage to vertical infiltration. If surrounded by dry land, simulated effective ground water recharge was estimated at 50-76\% of the total infiltration within a typical 48 ha rice paddy. However, this was reduced to $39-71 \%$ within a 12 ha rice growing area. Breaking the hard pan enhances the infiltration rate but also increases the seepage ratio. Thus, it was concluded that a flooded rice paddy performs a significant function in ground water conservation. Experimental and simulation results elucidate water movement mechanisms in rice paddies and clarify the vertical and horizontal flow processes within an unsaturated region. This work also provides a scientific basis to reevaluate water resource management in regions under irrigated rice. (C) 2002 Elsevier Science B.V. All rights reserved.
\end{abstract}

Keywords: Percolation; Seepage; Recharge; Simulation

\section{Introduction}

The first part of this work examined vertical water movement in paddy rice fields in the Ten-Chung region (Chen and Liu, 2002). The plow sole proved to be the key layer that controlled vertical infiltration in a

\footnotetext{
* Corresponding author. Tel.: + 886-2-2362-6480; fax: + 886-22362-9557.

E-mail address: 1cw@gwater.agec.ntu.edu.tw (C.W. Liu).
}

flooded paddy. Thus, breaking the plow sole could be a feasible approach to increase the infiltration rate.

Groundwater recharge from paddy rice fields that can be estimated via a field water balance equation are evaluated herein:

$I+R=E+T+S+P+D+\mathrm{d} W$

where $I$ is the irrigation supply; $R$, rainfall; $E$, evaporation; $T$, transpiration; $S$, lateral seepage; $P$, percolation; $D$, surface drainage or runoff; $\mathrm{d} W$ is the 
change in ponded water depth or water storage in the soil profile; all in $\mathrm{mm} /$ day.

Percolation that was defined in Eq. (1) is the vertical movement of water beyond the root zone to the water table, while lateral seepage is the movement of subsurface water from one field to the another (IRRI, 1965). Both of which are considered to be a primary water loss for farmers. However, as water percolates into an aquifer, it can be reused for irrigation or other purposes due to pumping. Therefore, percolation can no longer be considered an irrigation loss for current water resource management in Taiwan. When the water infiltrated the plow sole and progressed deeper, seepage moves laterally by the pressure head difference between fields. Furthermore, this decreases the amount of water that is recharged into the aquifer. Lateral seepage must be separated from infiltration in estimating the effectively ground water recharge from rice paddies quantitatively.

The hydraulic infiltration characteristics were employed to simulate water movement numerically, which includes infiltration and lateral seepage as well as the magnitude of effective percolation for ground water recharge. Several studies have identified lateral percolation as the main cause of low water-use efficiency in certain irrigated rice fields (Walker and Rushton, 1984; Tuong et al., 1994). Due to the decrease of rice production in Taiwan, many rice paddies only produce one crop annually, or have diverted to alternative crops. This resulted in a greater number of rice paddies that were scattered throughout dry fields. Therefore, during the quantitative groundwater recharge study, the effect of lateral seepage must be considered. A three-dimensional finite element computer model for simulating density dependent flow and transport (FEMWATER) was adopted to simulate the required tasks (Lin et al., 1996). A one-dimensional simulation algorithm for water flow in aquatic habitats (SAWAH) model, which ten Berge et al. (1992, 1995) developed has been use extensively in Asian nations, including Taiwan. Furthermore, it was compared with FEMWATER in different irrigation schemes that have been adopted in Taiwan. FEMWATER was then employed to conduct a series of numerical simulations to identify and evaluate the controlling factors in the vertical percolation/lateral seepage processes, and estimate ground water recharge that resulted from rice paddy infiltration. Recently, for easy maintenance, concrete bunds have replaced earth ones, therefore, the simulation did not account for lateral bund percolation (Walker and Rushton, 1984).

\section{Materials and methods}

\subsection{SAWAH}

A one-dimensional Darcy-based SAWAH soil/water flow model developed by ten Berge et al. (1992, 1995) was employed to solve the general flow equation under given boundary and initial conditions. This model can simulate saturated and unsaturated flow that simultaneously occur in varying soil profile sections in both upland and lowland, rained and irrigated rice environments where rice soils are layered and hydrology is highly dynamic with variable groundwater and volumetric soil water content (Wopereis et al., 1993; ten Berge et al., 1995). SAWAH uses explicit and implicit solution schemes for unsaturated and saturated sections of the soil profile, respectively. SAWAH accurately simulated ponded water depth and pressure head gradients within the soil profile for the test paddy rice field without seepage (Wopereis et al., 1994). Because of its high degree of detail, SAWAH has been adopted to evaluate the water-use efficiency and the feasibility of groundwater recharge under various soil-water conditions (Bouman et al., 1994; Liu and Chen, 1997; Liu, 1998).

\subsection{FEMWATER}

A three-dimensional FEMWATER finite element model developed by Lin et al. (1996) was used to differentiate the lateral seepage and vertical percolation from surface infiltration under varying wet and dry conditions in paddy rice fields, since the onedimensional SAWAH model cannot simulate both horizontal and vertical water movements. The ratio of lateral seepage to vertical infiltration was computed and the amount of deep percolation was determined to evaluate the effectiveness of ground water recharge from paddy rice fields.

The FEMWATER model was originally developed to numerically simulate fluid flow in a variable 
saturated porous media. It employs the Galerkin finite element method in space discretization and the finite difference method for time marching. Dirichlet, Neumann, Cauchy and variable boundary conditions of pressure, flux, and head are also incorporated into this model.

\subsection{Comparison of FEMWATER and SAWAH}

Infiltration rates simulated from the SAWAH and FEMWATER models were compared. Six simulation Scenarios (C1-C6) were provided in Table 1. Scenarios $\mathrm{C} 1-\mathrm{C} 3$ with initial pressure heads of 15 , 20 , and $25 \mathrm{~cm}$ at the top of plow sole were used in SAWAH to simulate the rotational irrigation scheme, while Scenarios C4-C6 with constant pressure heads of 15,20 , and $25 \mathrm{~cm}$ were used in FEMWATER for simulating the continuous irrigation scheme. The ponded water depth in paddy rice fields must maintain constant head conditions due to the limitations of FEMWATER modeling while external boundary conditions (irrigation, rainfall, evaporation, transpiration, water table depth) of SAWAH need to be specified daily.

The simulated region in SAWAH and FEMWATER was discretized into 10 grids. The first two grids with a grid spacing of $3.5 \mathrm{~cm}$ represented the plow sole. The grid spacing in the third grid was $2.5 \mathrm{~cm}$, while it was $25 \mathrm{~cm}$ from the fourth to the ninth grids. The grid spacing of the last grid was $20 \mathrm{~cm}$. The boundary condition at the bottom was set as a free drainage condition in the SAWAH simulation while the groundwater table was $9.8 \mathrm{~m}$ in the FEMWATER, the rotational irrigation time-step was 5 days and the evapotranspiration was set to $4 \mathrm{~mm} /$ day.

\subsection{FEMWATER simulations}

The soil water movement data of the Ten-Chung experimental paddy field was adopted herein. The soil profile was constructed according to Liu (1998) and Gea et al. (1994). The plow sole layer was $7.5 \mathrm{~cm}$ thick and had a hydraulic conductivity of $0.05 \mathrm{~cm} /$ day, which was followed by a $32.5 \mathrm{~cm}$ silt layer that had a hydraulic conductivity of $1.1 \mathrm{~cm} /$ day. The $7.4 \mathrm{~m}$ red loam layer and the $2 \mathrm{~m}$ black clayey loam layer, with hydraulic conductivities of 1.6 and $1.5 \mathrm{~cm} /$ day, respectively, were beneath the silt layer. The bottom
$100 \mathrm{~m}$ zone was treated as an unconfined aquifer that consisted of large gravel and various sized cobbles. This zone was highly permeable and had a hydraulic conductivity of $300 \mathrm{~cm} /$ day. Within the simulation, the ground water table depth, located at the bottom of the black clayey loam layer, was $9.8 \mathrm{~m}$. The unsaturated hydraulic conductivity curves and the soil water retention curves for different soil layers that were obtained from the Ten-Chung experimental fields were employed as model input data for the soil hydraulic characteristics.

The simulated region was $720 \mathrm{~m} \times 520 \mathrm{~m}$ and had a flooded and well-puddled rice paddy that was $720 \mathrm{~m} \times 360 \mathrm{~m}$ in the central region, and two blocks of dry land that were $720 \mathrm{~m} \times 80 \mathrm{~m}$ each in the south and north regions. The vertical finite element meshes in plow sole were refined with $0.035 \mathrm{~m}$ grid spacing, while other soil layers were discretized into 12 grids. The total modeling depth was $15 \mathrm{~m}$. The horizontal meshes at the dry to wet border were also refined with a minimum spacing of $0.15 \mathrm{~m}$, which were increased gradually to $40 \mathrm{~m}$ in the central area of the flooded fields. The horizontal hydraulic conductivity in alluvial formation is normally much greater than that in the vertical direction (Tood, 1959; Freeze and Cherry, 1979). Furthermore, the hydraulic conductivities in the horizontal direction were assumed to be two order larger than those in the vertical direction were. Within various conditions, the initial pressure heads of the flooded wet paddy were held as $-1.2 \mathrm{~m}$, while those on the dry land were $-1.2,-3.3$, and $-6.9 \mathrm{~m}$. Figs. 2 and 3 in part I present the pressure head in shallow subsoil that was proximal to -1.2 and -3.3 to $-6.9 \mathrm{~m}$ in flooded and dry areas, respectively. A no flow condition was established for the four sides of the simulated area and the constant pressure head was fixed as the surface boundary condition of the flooded fields.

The FEMWATER model was used to investigate the effects of initial water content of soil on lateral seepage and plow sole on infiltration. Table 2 presents eight simulation Scenarios $(\mathrm{F} 1-\mathrm{F} 8)$ that simulate the $3 \mathrm{D}$ water flow conditions:

Scenario F1. Initial pressure head of $-12 \mathrm{~m}$ in both flooded and dry fields was designed to represent a very dry soil condition. Constant pressure head of $0.2 \mathrm{~m}$ was assigned at the top of plow sole layer. 
Scenarios F2 - F4. Initial pressure heads of soil in dry land field were $-1.2,-3.3$, and $-6.9 \mathrm{~m}$, respectively, while $-1.2 \mathrm{~m}$ was assigned in the flooded area. Constant pressure heads of $0.2 \mathrm{~m}$ was assigned at the top of plow sole layer.

Scenarios F5-F7. Initial pressure head in both flooded paddy rice field and dry land was $1.2 \mathrm{~m}$, while the pressure heads at the top of the subsoil were $0.15,0.20$, and $0.25 \mathrm{~m}$, respectively. Plow sole was broken and mixed with the muddy layer.

Scenario F8. Conditions identical to F3, but there was no plow sole layer.

\section{Results}

\subsection{Validation and comparison of SAWAH and FEMWATER}

Results of the comparison between SAWAH and FEMWATER were presented in Table 1 and Figs. 1 and 2. Fig. 1 presents the simulated infiltration curves obtained from the SAWAH simulation with initial pressure head conditions of 15,20 , and $25 \mathrm{~cm}$ at the top of plow sole. The fluctuation of infiltration rate in Fig. 1 is resulted from the modeling of the rotational irrigation scheme by supplied irrigation water in the first day of a 5-day period. The average infiltration rates were 2.6, 3.4, and $4.1 \mathrm{~mm} /$ day, respectively. Fig. 2 presents the simulated infiltration curves realized from the FEMWATER simulation with constant head boundary conditions of 15,20 , and $25 \mathrm{~cm}$. The steadystate infiltration rates were $3.8,3.86$, and $4.1 \mathrm{~mm} /$ day, respectively, with a smaller variation than those obtained from the SAWAH. The pressure head in SAWAH simulations gradually decreased thereby reducing the steady-state infiltration rate accordingly. Comparing simulation and field experiment results where steady-state infiltration rates ranged from 2.9 to $7.7 \mathrm{~mm}$ /day for pressure heads from 20 to $30 \mathrm{~cm}$ and a $3.5 \mathrm{~mm} /$ day average infiltration rate, confirmed that experimental data and data from both simulations were congruent. Fig. 3 plots the pressure head distribution versus depth for field experiments and numerical simulations (both of the models with constant head boundary condition of $20 \mathrm{~cm}$, and after 30-day simulation). The general trends are similar and the pressure head distribution simulated by both models is almost identical. Thus, the FEMWATER model can be used to model water movement under constant head boundary condition in a flooded paddy rice field.

\subsection{Infiltration analysis}

Steady-state infiltration rates decreased from 5.5 to $3.8 \mathrm{~mm} /$ day in Scenarios $\mathrm{F} 1$ and $\mathrm{F} 2$ as the initial pressure head of subsoil in the flooded paddy rice fields declined from -12 to $-1.2 \mathrm{~m}$. The infiltration rate changed drastically but reached a steady-state after 60 days as illustrated in Fig. 4.

Varying the initial pressure head of soil in the dry land (see Table 2, Scenarios F2-F4), revealed that the infiltration rates changed similarly for all cases. Nevertheless, the steady-state infiltration rates for the initial pressure heads of $-1.2,-3.3$, and $-6.9 \mathrm{~m}$ of the dry land were $3.8,3.9$, and $4.1 \mathrm{~mm} /$ day, respectively. Thus, the steady-state infiltration rate increased with the initial pressure head difference between the dry and flooded fields. This finding cannot be differentiated in the one-dimensional SAWAH model.

Breaking the plow sole and setting the pressure heads at the top of subsoil as 15, 20, and $25 \mathrm{~cm}$ (Table 2, Scenarios F5-F7), resulted in infiltration rates of 12, 12.5, and $13.1 \mathrm{~mm} /$ day, respectively (see Fig. 5). Fig. 6 displays the development of infiltration rate curves with and without a plow sole. The steady-state infiltration rate in F6 (without plow sole) is $12 \mathrm{~mm} /$ day, which is approximately three times higher than that in F2 (with plow sole). The result is also congruent with the in situ measurements that breakage of the plow sole layer increased infiltration rate by a factor 3.7.

The results in Fig. 7 illustrate the changes of vertical infiltration flux at various locations within the flooded paddy rice fields (Scenario F3). The initial infiltration flux is substantially smaller at the boundary between dry land and flooded area because of the loss from lateral seepage. However, the infiltration flux increased over time and the vertical flux at the boundary of dry land and flooded paddy rice fields were supplied by both vertical percolation and lateral seepage after 20 days of simulation. Thus, it became larger than the vertical flux at other locations in the flooded area. 
Table 1

A comparison of simulated infiltration by SAWAH (Scenarios C1-C3) and FEMWATER (Scenarios C4-C6)

\begin{tabular}{llllll}
\hline Scenario & $\begin{array}{l}\text { Initial pressure head } \\
\text { at flooded paddy }(\mathrm{m})\end{array}$ & $\begin{array}{l}\text { Initial pressure head } \\
\text { at dry land }(\mathrm{m})\end{array}$ & $\begin{array}{l}\text { Ponded water } \\
\text { depth }(\mathrm{m})\end{array}$ & $\begin{array}{l}\text { Surface head } \\
\text { condition }\end{array}$ & $\begin{array}{l}\text { Groundwater table } \\
\text { depth }(\mathrm{m})\end{array}$ \\
\hline C1 & -1.2 & -1.2 & 0.15 & $\begin{array}{l}\text { Steady-state } \\
\text { infiltration rate } \\
(\mathrm{mm} / \text { day })\end{array}$ \\
C2 & -1.2 & -1.2 & 0.20 & Variable head & Free drainage \\
C3 & -1.2 & -1.2 & 0.25 & Variable head & Free drainage \\
C4 & -1.2 & -1.2 & 0.15 & Variable head & Free drainage \\
C5 & -1.2 & -1.2 & 0.20 & Constant head & 9.8 \\
C6 & -1.2 & -1.2 & 0.25 & Constant head & 9.8 \\
Constant head & 9.8 & 3.8 \\
\hline
\end{tabular}

Table 2

A summary of the simulated infiltration rate variations of varying initial dry/wet paddy pressure head, ponded water depth and with/without plow sole cases by FEMWATER

\begin{tabular}{lccccc}
\hline Scenario & $\begin{array}{c}\text { Initial pressure head at flooded } \\
\text { paddy rice field }(\mathrm{m})\end{array}$ & $\begin{array}{c}\text { Initial pressure head at dry } \\
\text { paddy rice field }(\mathrm{m})\end{array}$ & $\begin{array}{c}\text { Constant pressure head of upper } \\
\text { boundary condition }(\mathrm{m})\end{array}$ & Plow sole & Steady-state infiltration rate (mm/day) \\
\hline F1 & -12 & -12 & 0.20 & Yes & $5.5(60$ days) \\
F2 & -1.2 & -1.2 & 0.20 & Yes & 3.8 \\
F3 & -1.2 & -3.3 & 0.20 & Yes & 3.9 \\
F4 & -1.2 & -6.9 & 0.20 & Yes & 4.1 \\
F5 & -1.2 & -1.2 & 0.15 & No & 12.0 \\
F6 & -1.2 & -1.2 & 0.20 & No & 12.5 \\
F7 & -1.2 & -1.2 & 0.25 & No & 13.1 \\
F8 & -1.2 & -3.3 & 0.20 & No & 12.8 \\
\hline
\end{tabular}




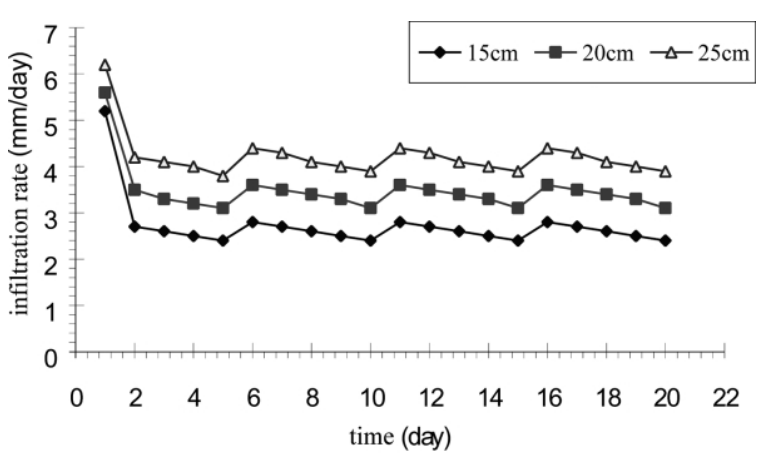

Fig. 1. SAWAH simulated infiltration rate with varying ponded water depth and variable head boundary conditions (Scenarios 1-3 in Table 1).

\subsection{Lateral seepage analysis}

The infiltration from the paddy consists of percolation and seepage. Percolation is the vertical movement of water beyond the root zone to the groundwater table, while seepage is the lateral movement of subsurface water (IRRI, 1965). These two movements are often practically inseparable (Wickham and Singh, 1978). The infiltration from flooded paddy rice fields may act as a source for ground water recharge. Therefore, the amount of lateral seepage must be quantitatively addressed to evaluate the effectiveness of ground water recharge from vertical infiltration in a paddy rice field. The FEMWATER model was utilized to simulate the lateral water movement from flooded paddy rice fields to dry land assuming initial pressure heads in the dry

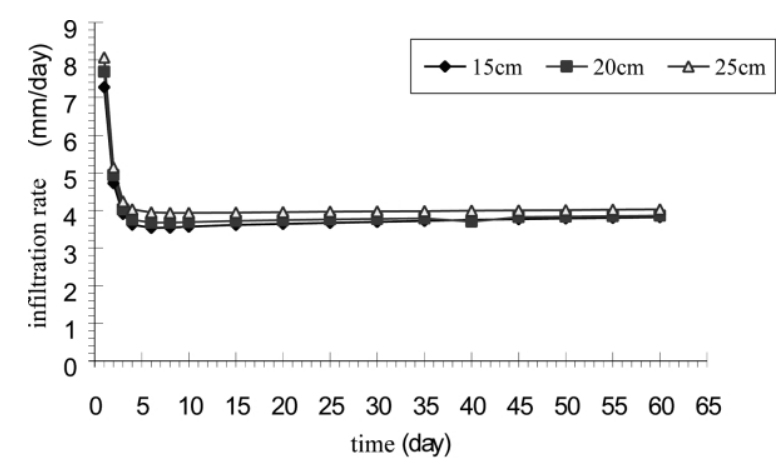

Fig. 2. FEMWATER simulated infiltration rate with varying ponded water depth under constant head boundary conditions (Scenarios 46 in Table 1).

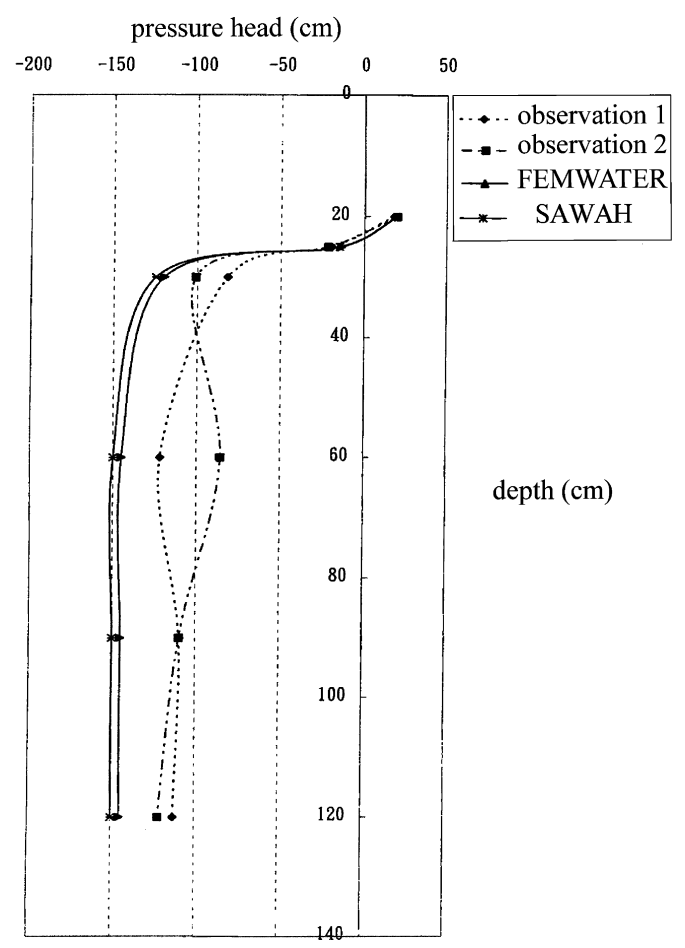

Fig. 3. A comparison of simulated and experimental pressure head profiles at the Ten-Chung experimental paddy rice field.

land and flooded paddy rice field of -3.3 and $-1.2 \mathrm{~m}$, respectively (Scenario F3).

The main affecting factors for lateral seepage inclusion of position and permeability of soil layers, initial soil moisture content in dry land/flooded paddy rice field and the boundary length of the dry land/flooded paddy rice field were further analysis as below.

\subsubsection{Position and permeability of soil layers}

Silt and red loam layers had higher seepage rates than the plow sole and black clayey loam as illustrated in Fig. 8 (Scenario F3). The lateral seepage rate in silt layer reached $12.1 \mathrm{~mm} /$ day after 30 days, whereas the seepage rate in the black clayey layer was practically zero. The infiltration flow in the flooded paddy rice field does not reach a really steady-state after 30 days because lateral seepage continued to develop in the dry land. It was obviously that soil layer with high permeability will not result in the greater seepage rate. The positions of soil layers also influence the seepage rate. As ponded water infiltrates across the plow sole, the silt layer (below the plow sole) with a permeability 


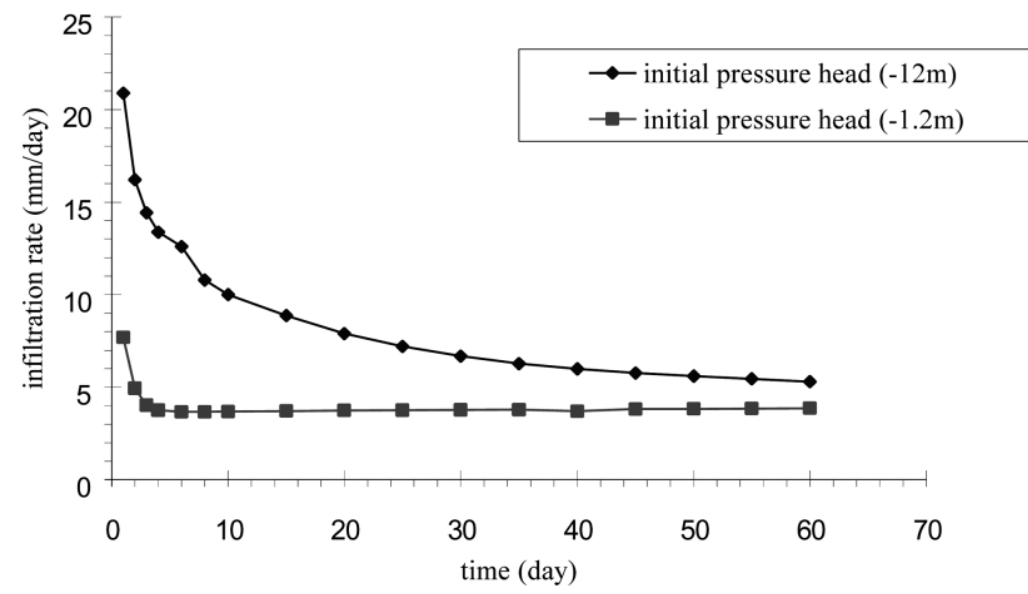

Fig. 4. FEMWATER simulated infiltration rates with varying initial pressure head cases at $20 \mathrm{~cm}$ ponded water depth (Scenarios F1 and F2).

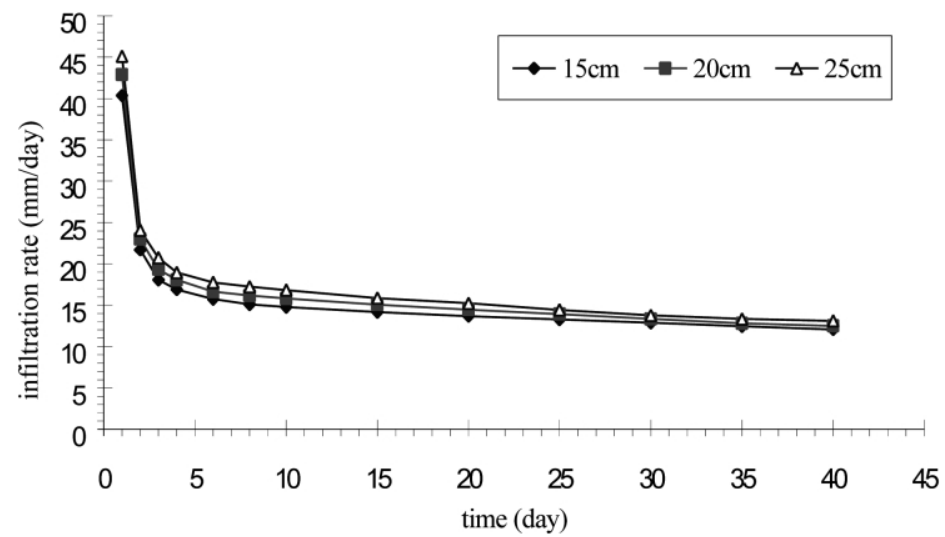

Fig. 5. FEMWATER simulated infiltration rate variations at varying ponded water depths without plow sole (Scenarios F5-F7).

lower than red loan and black clayey loam layers, will first receive replenished water from infiltration and yields a high seepage rate.

\subsubsection{Initial soil moisture content in dry land/flooded} paddy rice field

The initial pressure heads of soils were set to be $-1.2,-3.3$, and $-6.9 \mathrm{~m}$ in the dry land and $-1.2 \mathrm{~m}$ in the flooded paddy rice field with the pressure head $20 \mathrm{~cm}$ at the top of the plow sole (Scenarios F2-F4), to compare the flow distribution at various soil layers in the simulated field. The results can be summarized as below.

- Simulated percolation and seepage rates of various types of soil layers in the central flooded paddy

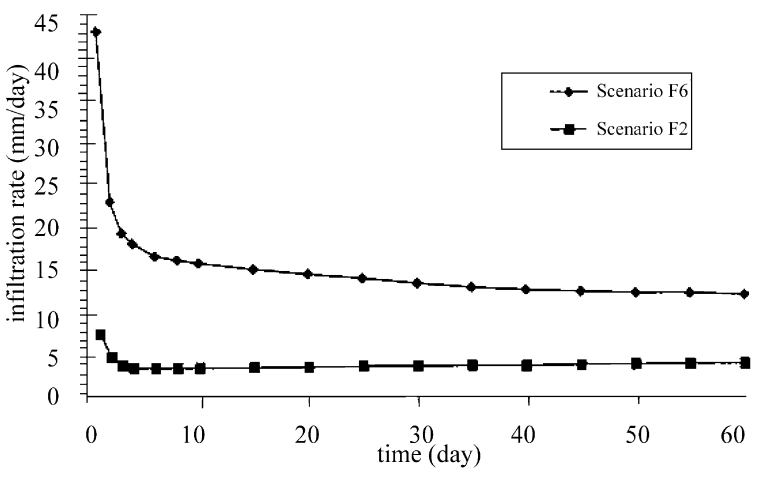

Fig. 6. A comparison of FEMWATER simulated infiltration rates with (Scenario F2) and without plow sole (Scenario F6) at $20 \mathrm{~cm}$ flooded water depth. 


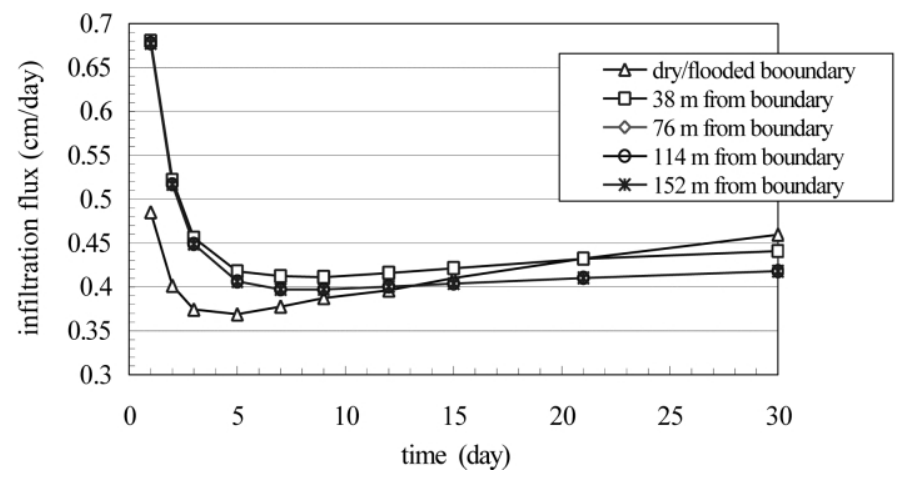

Fig. 7. FEMWATER simulated infiltration flux variations from the bottom of the plow sole at varying locations in a flooded paddy rice field, using parameters from Scenario F3 (Table 2).

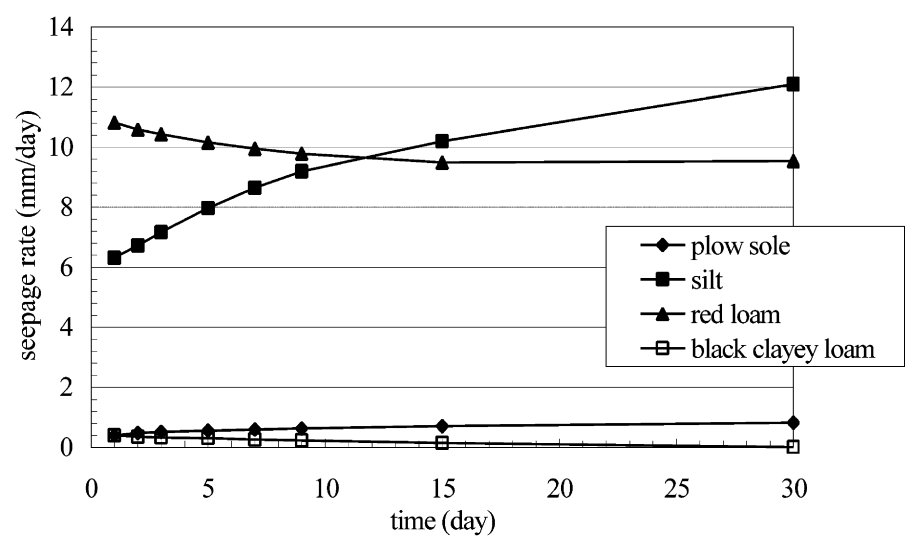

Fig. 8. FEMWATER simulated lateral seepage rate for varying soil layers at the dry/flooded boundary of a paddy rice field (Scenario F3, see Table 2).

demonstrated that the vertical flux was significantly greater than the lateral flux (approximately three orders in magnitude) as indicated in Fig. 9. This observation suggested that the water movement from infiltration dominated by the gravitational flow in the center region within a flooded paddy rice field.

- The simulated seepage rates in the center of a flooded paddy rice field, the boundary of dry land/flooded paddy rice fields, and the center of a dry land indicated that the lower initial pressure head in the dry land, the greater the seepage rate. The seepage rate at the boundary of the dry land/flooded paddy rice fields was three orders of magnitude larger than that in the central flooded area and one order of magnitude larger than that in

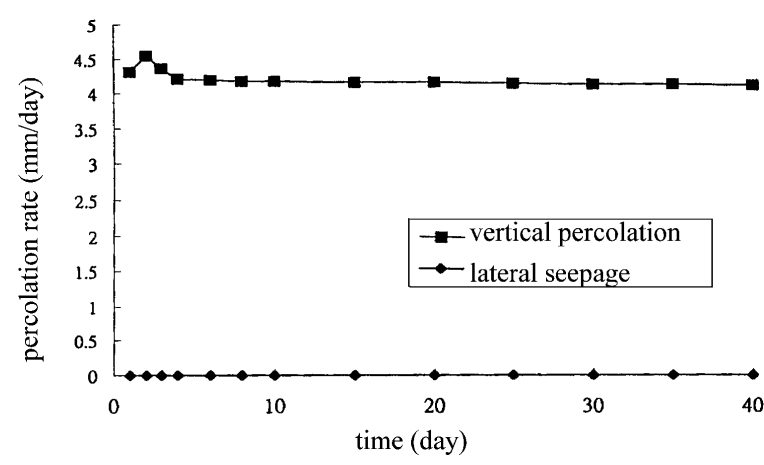

Fig. 9. FEMWATER simulated seepage and percolation rate as a function of time in the central flooded paddy where the initial pressure head in the dry and flooded paddy are -6.9 and $-1.2 \mathrm{~m}$, respectively (Scenario $\mathrm{F} 4)$. 


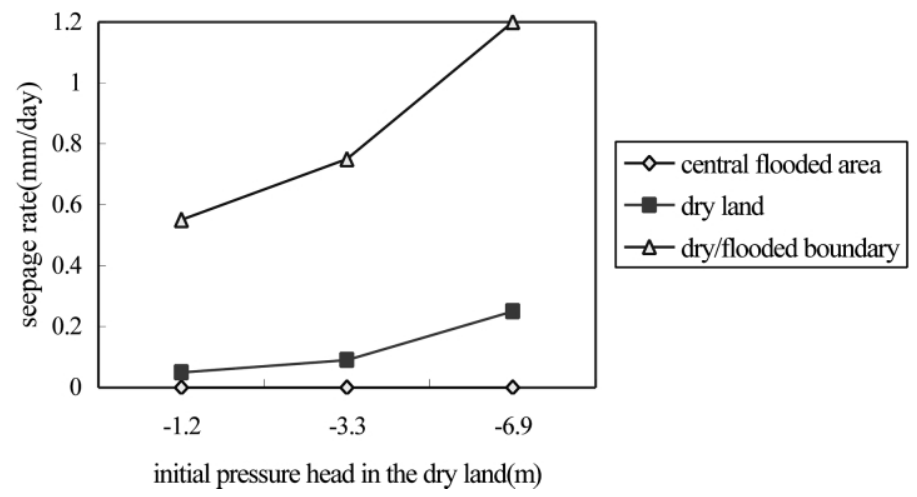

Fig. 10. A comparison of FEMWATER simulated seepage rate variation for varying initial pressure head conditions in the plow sole layer at varying locations in the dry land.

the dry land. Fig. 10 shows the seepage rates of the plow sole after a 30-day simulation under varying initial pressure head conditions in the central flooded field, the boundary of the dry land/flooded field, and the dry land, respectively.

- Simulated percolation and seepage rates of various soil layers at the boundary of the dry land and flooded paddy rice field after a 30-day simulation confirmed that the lateral flux was generally larger than the vertical flux if the initial pressure head of the dry land was smaller than that of the flooded paddy rice fields. However, the vertical flux became larger than the lateral flux if the initial pressure of the dry land and flooded field set equal. In such condition, the lateral flux just occurred in upper layers, inclusion of plow sole and silt layer, because the continuous water supplied by the ponded water will increase the pressure head in these layers, and seepage occurred even though the same initial pressure head in the beginning. Figs. 11 and 12 illustrate the simulated seepage rates in the silt layer and red loam layer, respectively.

- The simulated lateral flux attained a steady-state after a 30-day simulation and the daily lateral fluxes at initial pressure heads of $-1.2,-3.3$, and $-6.9 \mathrm{~m}$ (Scenarios F2-F4) in the dry land were 10,57 , and $121 \mathrm{~m}^{3}$, respectively. These lateral fluxes consist of $1,5.5$, and $11.3 \%$ of the daily infiltration fluxes from the surface flooded water.

\subsubsection{Boundary length of the dry land/flooded paddy} rice field

The effects of the boundary length of the dry land and flooded paddy rice field on infiltration in the flooded paddy area are further described as follows.

Assuming the length and width of a paddy are $a$ (m) and $b(\mathrm{~m})$, respectively, the infiltration rate is $f$ $(\mathrm{mm} /$ day), the thickness of varying types of soil layers

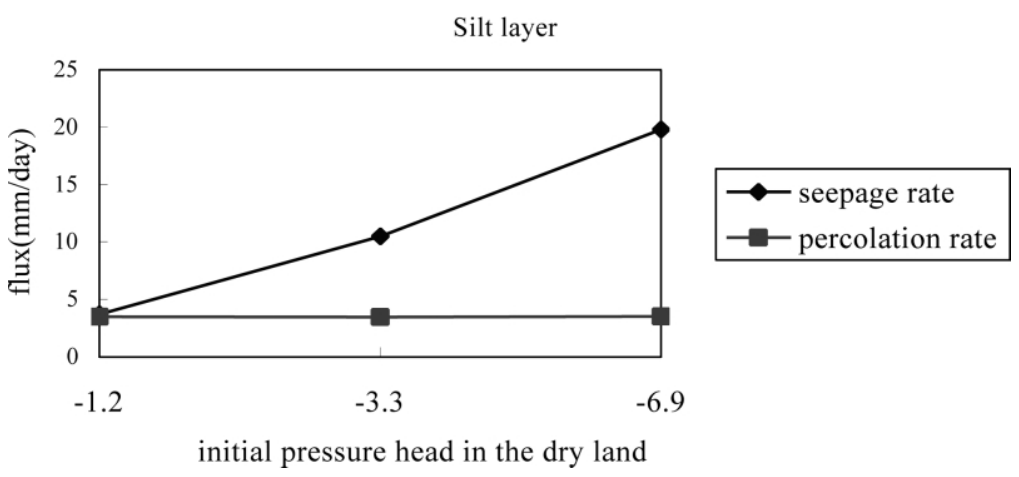

Fig. 11. A comparison of FEMWATER simulated seepage and percolation rate variations for varying initial pressure head conditions in the silt layer at the dry/flooded boundary (Scenarios F2-F4, see Table 2). 


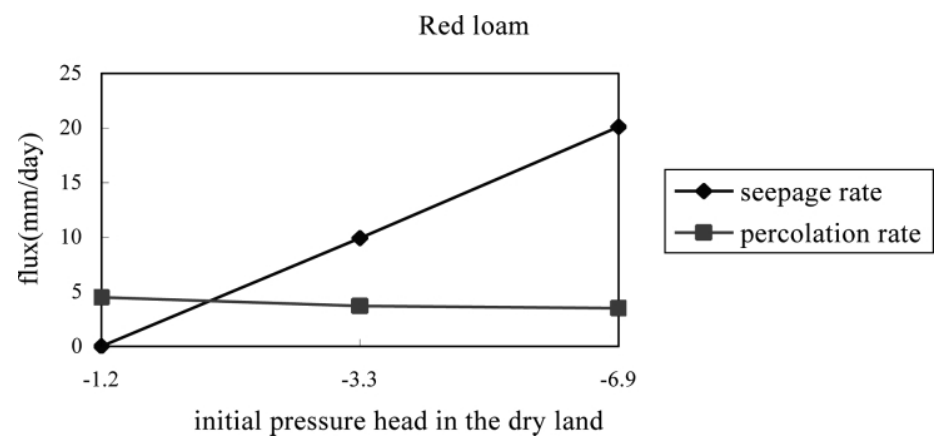

Fig. 12. A comparison of FEMWATER simulated seepage and percolation rate variations for varying initial pressure head conditions in the red loam layer at the dry/flooded boundary (Scenarios F2-F4, see Table 2).

from the top to the bottom layers are $D_{1}, D_{2}, D_{3}, \ldots$, and its corresponding lateral seepage rates are $L_{1}, L_{2}, L_{3}, \ldots$. The ratio of total lateral seepage to total infiltration can be calculated via the principle of mass conservation where the daily vertical infiltration $(Q)$ cross the plow sole in a flooded paddy rice field is

$Q=a \times b \times f$

The daily lateral seepages of varying types of soil layers are:

$2(a+b) \times D_{1} \times L_{1}, \quad 2(a+b) \times D_{2} \times L_{2}$,

$2(a+b) \times D_{3} \times L_{3}, \ldots$

After summation, the total daily lateral seepages are:

$2(a+b)\left(D_{1} L_{1}+D_{2} L_{2}+D_{3} L_{3}\right)$

Therefore, the ratio of total lateral seepage to total infiltration of a rectangular-shaped flooded field surrounded by four sides of dry land is equal to:

$2(a+b)\left(D_{1} L_{1}+D_{2} L_{2}+D_{3} L_{3}+\cdots\right) / a b f$

Eqs. (2)-(5) can be utilized to compute the infiltration flux and lateral seepage flux by the FEMWATER simulation. The major lateral seepage flux for a paddy rice field occurred along the boundary of the dry land and flooded paddy rice fields. Thus, reducing the area or increasing the boundary length will result in the more lateral seepage loss. For example, a Taiwanese rotational irrigation area generally consists of four irrigation units with a total area of 48 ha. Assuming the rotational irrigation area surrounded by dry land and the boundary length of dry/flooded areas was $5200 \mathrm{~m}$ in average, the simulated groundwater recharge was 76 and $50 \%$ of the total infiltration, if the initial pressure heads in dry land were -3.3 and

time (day)

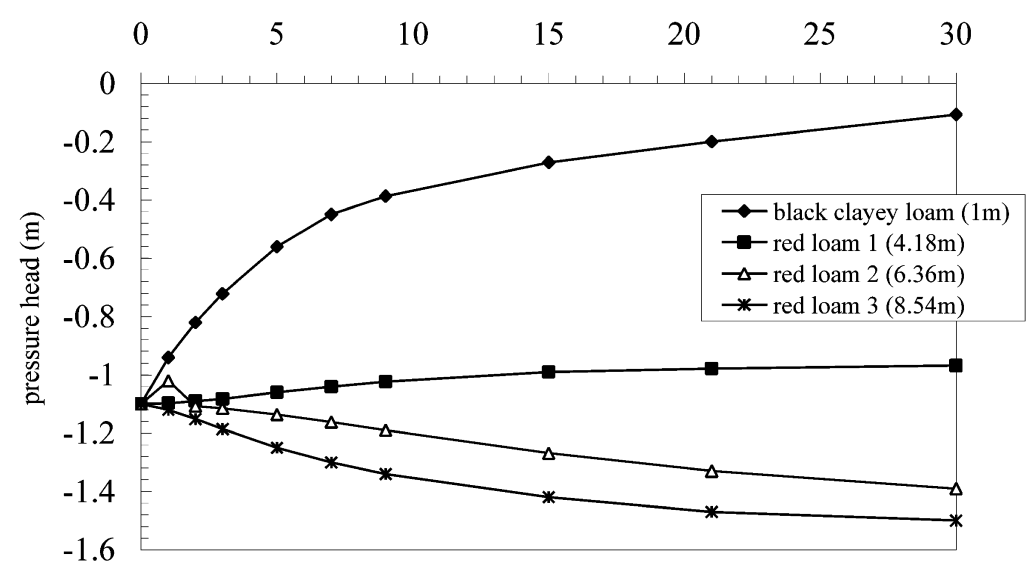

Fig. 13. FEMWATER simulated pressure head variation of the soil layer above the groundwater table (Scenario F3). 
$-6.9 \mathrm{~m}$ (using the parameters of Scenarios F3 and $\mathrm{F} 4)$, respectively. But for a single irrigation unit with the area of 12 ha $\left(200 \times 600 \mathrm{~m}^{2}\right)$ surrounded by four sides of dry land, the simulated daily lateral seepage increased to 29 and $61 \%$ of total daily infiltration, and the effective ground water recharge rate decreased to 71 and $39 \%$ of the total infiltration.

\subsection{Effective ground water recharge}

The deep percolation from the flooded field became a source for ground water recharge since it can enter the shallow ground water aquifer. Fig. 13 illustrates that establishing the initial pressure head of $-3.3 \mathrm{~m}$ in the dry land (Scenario F3) simulated the pressure head variations in the black clayey and red loam layers. After 30 days of simulation, the pressure head in the back clayey loam layer gradually increased and attained $-0.1 \mathrm{~m}$, which indicates that the water accumulation increased significantly and became a source for ground water recharge.

The pressure head in the third grid of the red loam decreased initially owing to lateral seepage, however, it increased gradually following a 10-day simulation due to the increase in the ground water table that deep percolation produced. The vertical flux across the horizontal grids, which were positioned $2 \mathrm{~m}$ above the original ground water table, was computed and employed to evaluate the effective ground water recharge. This subsequently facilitated quantitative analyses of the recharge from deep percolation. Fig. 14 displays that the simulated effective ground water recharge rates were 4 and $7 \mathrm{~mm} /$ day in the cases with and without plow sole layer, respectively (Scenarios F3 and F8). As well, following 30 days of simulation, the ground water recharge was 31,603 and $55,770 \mathrm{~m}^{3}$ in the cases with and without plow sole layer, respectively. A comparison of the infiltration ratio that were both with and without plow sole layer (Table 2, Scenarios F3 and F8) confirmed that the lateral seepage ratio increased significantly from 5.5 to $41 \%$ when there was no plow sole layer. Although breaking the hard pan enhances the infiltration rate, it simultaneously increases the seepage rate.

With a total area of 35,700 ha in the upper portion of the Chou-Shui-Alluvial fan in Taiwan, and two terms of annual rice cultivation, in early 1980s the infiltration amount from paddy rice fields was estimated to be as 228.5 million $\mathrm{m}^{3}$. Notably, this was based on the simulated average infiltration rate of $4 \mathrm{~mm}$ /day (see Table 2, Scenarios F3 and F4) as well as the total of 160 flooding days that occurred during two crop periods. It was believed that the groundwater recharge amount would be similar to this infiltration amount because most of the irrigation units were adjacent, which thus reduced the dry to wet boundary length. However, due to the recent socio-economic changes, approximately one third of rice paddies have been diversified for other crops, and the second rice crop has practically ceased in the remaining fields. The amount of infiltration from rice paddies was reduced to 76.2 million $\mathrm{m}^{3}$. It would be extremely difficult to quantify the entire recharge amount from paddy rice fields' infiltration in this area now, because as rice paddies are increasingly becoming surrounded by dry fields. For typical rotational irrigation area that

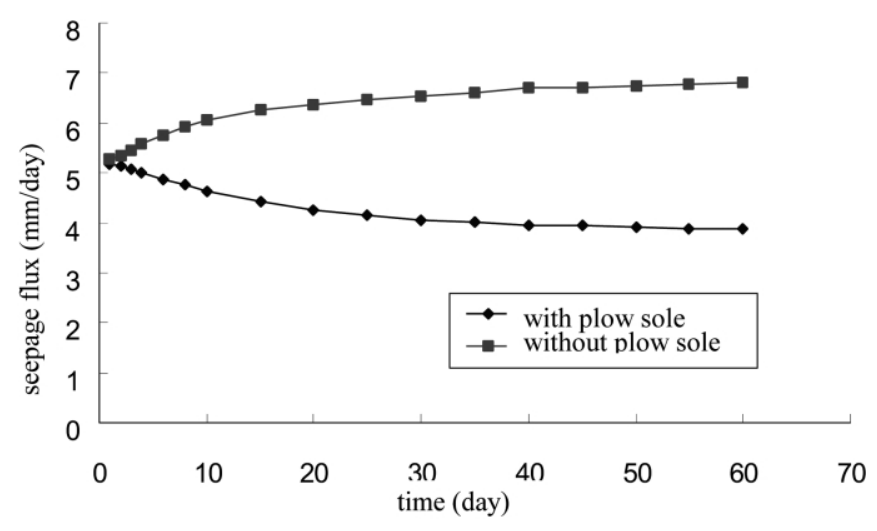

Fig. 14. A comparison of FEMWATER simulated seepage flux with (Scenario F3) and without plow soil (Scenario F8). 
is surrounded by dry land, the effective ground water recharge rate can produce a conservative estimation of $50-76 \%$. The estimated amount of annual effective ground water recharges in this area is projected to range from 38.1 to 57.9 million $\mathrm{m}^{3}$. The decrease of ground water recharge is significant since it equals a medium-size reservoir in Taiwan. Therefore, infiltration from a flooded paddy should be considered as an essential source of ground water recharge.

\section{Conclusion}

The research mainly aims to study the mechanisms for infiltration/lateral seepage of local paddy field on groundwater recharge so as to provide bases for drawing up feasible methods that can increase the groundwater recharge of paddy fields in Taiwan. Simulations were carried out based on the soil/hydraulic characteristics of the experimental paddy fields at an alluvial fan area of Chuo-Shui River in Ten-Chung, Chang-Hwa. Comparing with onedimensional SAWAH and three-dimensional FEMWATER, the former because of its high degree of detail, was very suitable for simulating the complicated rotational irrigation scheme now adopted in Taiwan. The FEMWATER, for its limitation on constant head condition of external boundary, only suitable for continuous irrigation scheme, however, when lateral seepage and vertical infiltration must be simultaneously considered on effective groundwater recharge evaluation, the three-dimensional FEMWATER model was valid to carry out such simulations.

Simulation results showed that the water movement mainly vertical percolation within a paddy field, the plow sole was the major factors controlling the infiltration rate and groundwater recharge in paddy rice fields. Infiltration rate increased significantly if without plow sole. Apparent lateral seepage may only occur nearby the border between a dry land and a flooded paddy field. The better the soil permeability and the drier the soil in the dry land, the higher the lateral seepage rate. Permeability of soil layers, water content of soils in dry land/flooded paddy rice fields, length of dry/wet border, and total area of flooded paddy rice fields are all key affecting factors for calculating the proportion of lateral seepage in overall infiltration water volume. Inevitably, different calculation bases will result in different results. If a smallsized flooded paddy field surrounded by dry land, the ratio of effective groundwater recharge will reduce. Therefore, if paddy rice fields are dispersedly distributed in the dry fields, the border length will become longer and, subsequently, the lateral seepage ratio will be increased. Simulated effective ground water recharge was estimated at $50-76 \%$ of total infiltration for a typical 48 ha rice growing area surrounded by dry land, but reduce to $39-71 \%$ for a 12 ha rice growing area. Breaking the hard pan can enhance the infiltration rate but also simultaneously increase the seepage rate. It is suggested that largesized paddy rice fields consisted of several adjoining typical rice growing blocks should be planned so as to enhance the groundwater recharge in this area. Although the simulation results do not cover every situation, they offer a coherent and logical strategy for increasing groundwater recharge from paddy rice fields.

\section{Acknowledgments}

The authors would like to thank the National Science Council and Council of Agriculture of the Republic of China for financially supporting this research under Contract Nos. NSC-88-2625-E-002022 (IV) and 88-NOUCHAN-8.5-LIN-02.

\section{References}

Bouman, B.A.M., Wopereis, M.C.S., Kropff, M.J., ten Berge, H.F.M., Tuong, T.P., 1994. Water use efficiency of flooded rice fields. (II) Percolation and seepage losses. Agricultural Water Management 26, 291-304.

Chen, S.K., Liu, C.W., 2002. Analysis of water movement in the paddy rice fields. (I) Experimental studies. Journal of Hydrology 260, 206-215.

Freeze, R.A., Cherry, J.A., 1979. Groundwater, Prentice-Hall, Englewood Cliffs, NJ, pp. 30-36.

Gea, Y.P., Liu, C.W., Horng, R.T., 1994. Hydrogeologic framework and conceptional ground water flow model for the Yun-Lin area, Conference on Groundwater Resources and Quality Protection, Taiwan, pp. 77-99.

IRRI, 1965. Annual Report 1964. International Rice Research Institute, Los Banos, Philippines, p. 335.

Lin, H.C., Richards, D.R., Yeh, G.T., Cheng, J.R., Cheng, H.P., 
Jones, N.L., 1996. FEMWATER: a three-dimensional finite element computer model for simulating density dependent flow and transport. Technical Report, HL-96.

Liu, C.W., 1998. Evaluation of Alternative Strategies for Increasing Groundwater Recharge from Rice Paddy Field: Infiltration and Classification of the Contributions to Non-Irrigated-Area Groundwater Recharge, Bureau of Hydraulics, Taiwan.

Liu, C.W., Chen, S.K., 1997. Natural Recharge of Groundwater in the Areas from Tai-Shi to Mai-Lau, Taiwan (II), Department of Agricultural Engineering, National Taiwan University, Taipei, Taiwan.

ten Berge, H.F.M., Jansen, D.M., Rappoldt, K., Stol, W., 1992. The soil water balance model SAWAH: User's guide and outline, CABO-TPE Simulation Reports Series 22, CABO, Wageningen, Netherlands.

ten Berge, H.F.M., Metselaar, K., Jansen, M.J.W., de San Agustin, E.M., Woodhead, T., 1995. The SAWAH riceland hydrology model. Water Resource Research 31, 2721-2732.

Tood, D.K., 1959. Groundwater Hydrology, Wiley, New York, pp. $78-81$.
Tuong, T.P., Wopereis, M.C.S., Marquez, J.A., Kropff, M.J., 1994. Mechanisms and control of percolation losses in irrigated puddled rice fields. Soil Science Society of America Journal 58, 1794-1803.

Walker, S.H., Rushton, K.R., 1984. Verification of lateral percolation losses from irrigated rice fields by a numerical model. Journal of Hydrology 71, 335-351.

Wickham, T.H., Singh, V.P., 1978. Water movement through wet soil, Soils and Rice, International Rice Research Institute, Los Banos, Philippines, pp. 337-357.

Wopereis, M.C.S., Wosten, J.H.M., ten Berge, H.F.M., Woodhead, T., de San Agustin, E.M., 1993. Comparing the performance of a soil-water balance model using measured and calibrated hydraulic conductivity data: a case-study for dry land rice. Soil Science 156, 133-140.

Wopereis, M.C.S., Bouman, B.A.M., Kroff, M.J., ten Berge, H.F.M., Maligaya, A.R., 1994. Water use efficiency of flooded rice fields. (I) Validation of the soil-water balance model SAWAH. Agricultural Water Management 26, 291-304. 